\title{
Anti-Toxoplasma gondii antibodies in patients with beta-hemoglobinopathies: the first report in the Americas
}

\author{
Marina Neves Ferreira ${ }^{1,2,3,7}$, Claudia Regina Bonini-Domingos ${ }^{1}$, Isabeth Fonseca Estevão ${ }^{1}$, \\ Clarice Lopes de Castro Lobo ${ }^{4}$, Gisele Cristina Souza Carrocini' , Aparecida Perpétuo Silveira-Carvalho 2,3, \\ Octávio Ricci Jr $r^{5,6}$, Luiz Carlos de Mattos ${ }^{2,3}$ and Cinara Cássia Brandão de Mattos ${ }^{2,3^{*}}$ (1)
}

\begin{abstract}
Background: In Brazil, there have been no previous studies of Toxoplasma gondii infection in sickle cell anemia patients and carriers of severe forms of beta-thalassemia. This study evaluated T. gondii infection in patients with beta-hemoglobinopathies.
\end{abstract}

Methods: A total of 158 samples, 77 (48.7\%) men and 81 (51.3\%) women, were evaluated. Three groups were formed: G1 (85 patients with sickle cell disease); G2 (11 patients with homozygous beta-thalassemia; G3 (62 patients with heterozygous beta-thalassemia). ELISA was employed to identify anti-T. gondii IgM and IgG antibodies, and molecular analysis was performed to determine beta-hemoglobin mutations. Fisher's exact test was used to compare frequencies of anti-T. gondii lgM and IgG antibodies in respect to gender and age.

Results: Anti-T. gondii lgG antibodies were found in 43.5\% of individuals in G1, 18.1\% in G2 and 50\% in G3. All samples from G1 and G2 were seronegative for anti-T. gondii IgM antibodies, but 3.2\% from G3 were seropositive. Considering anti-T. gondii lgG antibodies, no statistical significant differences were found between these groups nor in seroprevalence between genders within each group. Despite this, comparisons of the mean ages between G1, G2 and G3 were statistically significant (G2 vs. G1: p value =0.0001; G3 vs. G1: p-value <0.0001; G3 vs. G2: p-value =0.0001).

Conclusion: A comparison by age of patients with sickle cell anemia showed a trend of lower risk of infection among younger individuals. Therefore, this study demonstrates that T. gondii infection occurs in patients with beta-thalassemia and sickle cell anemia in Brazil as seen by the presence of anti-T. gondii lgM and IgG antibodies.

Keywords: Beta hemoglobinopathies, Toxoplasma gondii, Toxoplasmosis, Sickle cell disease, Beta-thalassemia

\section{Background}

Sickle cell disease is a hereditary hemoglobinopathy characterized by the presence of hemoglobin $(\mathrm{Hb}) \mathrm{S}$, generated from a point mutation in the $\beta$-globin gene. Homozygosity for this point mutation leads to severe anemia with clinical manifestations such as hemolytic

\footnotetext{
*Correspondence: Cinara.Brandao@famerp.br; Cinara.Brandao@live.com ${ }^{2}$ Immunogenetics Laboratory, Department of Molecular Biology, Faculdade de Medicina de São José do Rio Preto-FAMERP, Avenida Brigadeiro Faria Lima, 5416, São José do Rio Preto, SP 15090-000, Brazil Full list of author information is available at the end of the article
}

anemia, pain crises, infections, ulcers and recurrent vasoocclusive events $[1,2]$.

In Brazil, this is the most common hereditary disease due to the influence of African descendants in the composition of the population and, in particular, to the high rate of miscegenation [3, 4]. Transfusions of red blood cells are very important to sickle cell disease patients, as this can reduce or even prevent acute and chronic complications.

Beta-thalassemia is the most common autosomal recessive inheritance disorder worldwide. The variability in the disease phenotypes ranges from clinically asymptomatic to severe anemia $[5,6]$. 
Despite the benefits that blood transfusions offer to patients with beta-thalassemia, some risks should be considered such as the high transmission risk of infectious agents (viruses, bacteria and parasites). In fact, cases of malaria and Chagas disease have been identified after blood transfusions [7-10]. Infections, mainly septicemia and pneumonia, account for $45 \%$ of deaths in sickle cell disease children, even though these infections are not necessarily acquired by transfusions $[11,12]$.

Toxoplasmosis is a globally prevalent zoonotic disease caused by the obligate intracellular parasite Toxoplasma gondii (Phylum Apicomplexa), which mainly infects birds and mammals, including man. Transmission is primarily by eating raw or undercooked meat containing cysts of the parasite and consuming food and water contaminated with oocysts. However, there are other ways to get infection, such as through transplants and blood transfusions, as well as congenital transmission [13-16].

Siegel et al. [17] described one of the first instances of $T$. gondii transmission by the transfusion of blood products in which four immunocompromised individuals developed toxoplasmosis. Screening for antiT. gondii in donated blood is not compulsory in many countries, including Brazil, but studies have shown the importance of this transmission route $[18,19]$. Despite the inherent risk, there are many questions about the effectiveness of implementing testing to identify toxoplasmosis [20].

Karakaş et al. [21], in a study conducted with beta thalassemia major patients in Aydin Province, Turkey, investigated the possible relationship between $T$. gondii infection and blood transfusions that these patients received. They found that seropositivity for anti-T. gondii antibodies of the analyzed group was greater than a control group, but no statistical significance was verified. Given the fact that no previous studies have investigated T. gondii infection in patients with beta-thalassemia and sickle cell anemia in Brazil, the aim of this study was to evaluate the presence of anti-T. gondii IgM and IgG antibodies in patients with beta-thalassemia major and intermedia and with sickle cell anemia diagnosed and treated in three referral centers.

\section{Methods}

\section{Ethical aspects of the study}

This study was approved by the Ethics Committees of the Universidade Estadual Paulista "Júlio de Mesquita Filho", Instituto de Biociências, Letras e Ciências Exatas (UNESP/IBILCE), and the Faculdade de Medicina in São José do Rio Preto (FAMERP) and the Instituto de Hematologia Arthur de Siqueira Cavalcanti, Rio de Janeiro (HEMORIO). Individuals who agreed to participate were informed about the nature of the study and all subjects and the patents or legal guardians of under 18-years-old signed informed consent forms.

\section{Patients}

This study enrolled 158 patients attended at three referral centers for the treatment of beta hemoglobinopathies in southeastern Brazil (the Hemocentro de São José do Rio Preto, SP, the Instituto Estadual de Hematologia Arthur de Siqueira Cavalcanti-HEMORIO, Rio de Janeiro, RJ and a private clinic in the city São Carlos, SP). All patients signed a consent form allowing their participation on this study.

The patients were allocated to three groups: G1 (85 patients with sickle cell disease); G2 (11 patients with homozygous beta-thalassemia, two clinically classified as beta-thalassemia intermedia and nine as beta-thalassemia major) and G3 (62 patients with heterozygous beta-thalassemia).

Carriers of sickle cell anemia and beta thalassemia major receive regular blood transfusions because this is the most appropriate and effective treatment. Otherwise, the rate of transfusions for thalassemia intermedia carriers is variable and may not be regular. In general, patients with sickle cell anemia receive blood transfusions when the hemoglobin level is $6 \mathrm{~g} / \mathrm{dL}$ or lower. All sickle cell anemia patients were on regular treatment using hydroxyurea and the disease was controlled.

The nine beta thalassemia major patients were receiving transfusions every 15 or 21 days, but the two beta thalassemia intermedia patients were not receiving regular blood transfusions. None of these patients was using hydroxyurea.

Diagnosis of these hematological disorders occurs soon after birth or within the first few years of life due the severe symptoms.

The 62 individuals with heterozygous beta thalassemia are asymptomatic and did not receive blood transfusions. They were analyzed to compare the prevalence of $T$. gondii infection in individuals that received regular transfusions and in those that did not.

Figure 1 shows the realized steps to diagnose hematological disorders and $T$. gondii infection in this research.

\section{Blood sampling}

Blood samples were collected in tubes with ethylenediaminetetraacetic acid (EDTA). An investigation of $T$. gondii infection (IgM and IgG antibodies) was made and DNA was extracted from leukocytes.

\section{Detection of anti-T. gondii IgM and IgG antibodies}

Anti-T. gondii IgM and IgG antibodies were investigated using the enzyme-linked immunosorbent assay (ELISA) test with the ETI-TOXOK (IgM) and ETI-TOXOK (IgG) 


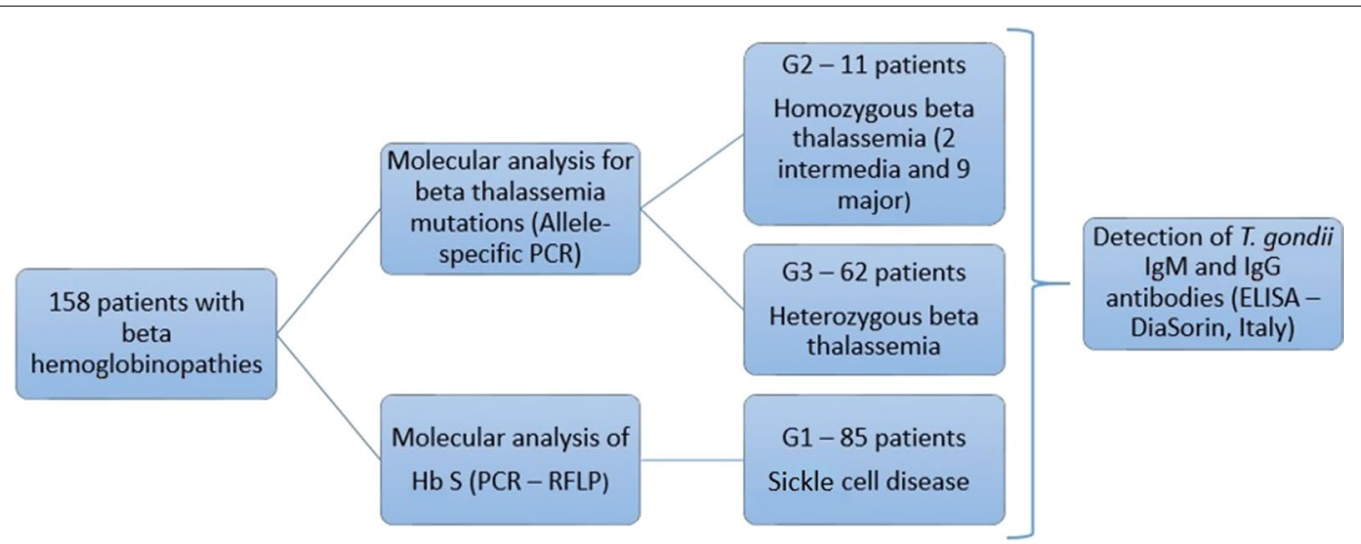

Fig. 1 Flow diagram showing the methodology that were conducted in the analyzed samples, for diagnosis of hematological disorders and infection of T. gondii

commercial kits (DiaSorin, Saluggia, Italy) according to manufacturer's instructions.

\section{Molecular diagnosis of beta-thalassemia}

Genomic DNA was extracted from peripheral blood samples and DNA purity was determined by the ratio of optical density (OD) at 260 and $280 \mathrm{~nm}$ in a NanoDrop ND100 spectrophotometer (Thermo Scientific, USA). DNA samples were diluted to a final concentration $100 \mathrm{ng} / \mu \mathrm{L}$.

\section{Molecular analysis of $\mathrm{Hb} \mathrm{S}$ by polymerase chain reaction-restriction fragment length polymorphism (PCR- RFLP)}

Detection of the Hb S mutation was by PCR-RFLP [22]. The primers used for the amplification of codon 6 were the P 277 primer (sense): $5^{\prime}$ GGC AGA GCC ATC TAT TGC TTA $3^{\prime}$ and the $\mathrm{P} 278$ primer (antisense): $5^{\prime}$ ACC TTA GGG TTG CCC ATA AC $3^{\prime}$. After amplification, the 382 bp fragment was digested by the FastDigest $D d e \mathrm{I}$ restriction enzyme at $37^{\circ} \mathrm{C}$ for 5 mins. $\mathrm{Hb} \mathrm{S}$ eliminates the restriction site for the $D d e \mathrm{I}$ enzyme, so fragments of 6, 88 and 288 bp are produced (the first one is not seen in agarose gel). Fragments of $6,87,88$ and 201 bp are identified in the absence of this mutation.

\section{Molecular analysis of beta-thalassemia mutations by allele-specific PCR}

Because high frequencies of some mutations of betathalassemia are found in the Brazilian population $[23,24]$, the following were investigated: CD39 (HBB: c.118C >T), IVSI-110 (HBB: c.93-21G>A), IVSI-6 (HBB: c. $92+6 \mathrm{~T}>\mathrm{C}$ ) and IVSI-1 (HBB: c. $92+1 \mathrm{G}>\mathrm{A}$ ). Detection of these mutations was performed by allele-specific PCR, using the PS39 W (5' GAC TCA AAG AAC CTC TG $3^{\prime}$ ) and PS39M primers (5' GAC TCA AAG AAC CTC TA $\left.3^{\prime}\right)$ for the CD39 mutation; the TB110W (5' GGG TGG GAA AAT AGA CC $3^{\prime}$ ) and TB110M primers (5' GGG TGG GAA AAT AGA CT $3^{\prime}$ ) for the IVSI-110 mutation; the IVSI6W (5' GTC TTG TAA CCT TGA TA $\left.3^{\prime}\right)$ and IVSI6M primers (5' GTC TTG TAA CCT TGA TG $\left.3^{\prime}\right)$ for the IVSI- 6 mutation and the IVSI1W ( $5^{\prime}$ GTG ACC TTG ATA CCA AC $3^{\prime}$ ) and IVSI1M primers (5' GTG ACC TTG ATA CCA AA 3') for IVSI-1 mutation. [25].

\section{Statistical analysis}

The results were compared using the GraphPad statistics program (version 3.1). The T-test was used to compare mean ages. Fisher's exact test was used to compare frequencies of anti-T. gondii IgM and IgG antibodies in respect to gender and age. Moreover, Odds Ratio and the 95\% confidence interval were calculated. Statistical significance was set for an alpha error of $5 \%$ (p-value $<0.05$ ).

\section{Results}

A total of 158 blood samples-from 77 (48.7\%) men and 81 (51.3\%) women-were tested. The distribution of gender in each group is shown in Table 1.

The mean ages were $29.7 \pm 15.0,27.4 \pm 18.0$ and $51.2 \pm 18.0$ years for groups G1, G2 and G3, respectively. The mean age of the heterozygous beta-thalassemia

Table 1 Stratification by gender in each of the analyzed groups

\begin{tabular}{lccc}
\hline & Male, $\mathbf{n}(\%)$ & Female, $\mathbf{n}(\%)$ & Total, $\mathbf{n}$ \\
\hline G1 & $39(45.8)$ & $46(54.1)$ & 85 \\
G2 & $8(72.7)$ & $3(27.3)$ & 11 \\
G3 & $30(48.3)$ & $32(51.61)$ & 62 \\
\hline
\end{tabular}

G1 sickle cell disease patients, G2 homozygous beta-thalassemia patients, G3 heterozygous beta-thalassemia minor patients 
carriers (G3) was higher than the sickle cell anemia (G1) and homozygous beta-thalassemia patients (G2). Comparisons of the mean ages between groups were statistically significant (G2 vs. G1: p-value $=0.0001 ; \mathrm{G} 3$ vs. G1: p-value $<0.0001$; $G 3$ vs. $G 2$ : p-value $=0.0001$ ).

All samples from G1 and G2 were seronegative for antiT. gondii IgM antibodies, thus, comparisons between groups were made considering only results for anti- $T$. gondii IgG antibodies (Table 2). No statistical significant differences were found between groups with regard to positive and negative serology for anti- T. gondii IgG antibodies. Moreover, there were no statistically significant differences in seroprevalence for anti-T. gondii antibodies between genders within each group.

For further analyses, the individuals of each group were classified as pediatric or adult patients; under 18 year olds were categorized as pediatric patients. The seroprevalence for anti- $T$. gondii antibodies of these subgroups was analyzed in Table 3 . The age comparison of patients with sickle cell anemia indicates that there is a trend of lower risk of infection among younger individuals (pediatric patients). This condition was not observed in beta-thalassemia patients because there were no under 18-year-old patients in G3 and the number of homozygous beta-thalassemia individuals infected (G2) was very small.

\section{Discussion}

The frequency of T. gondii infection is high in the states of São Paulo and Rio de Janeiro, especially when considering the population of pregnant women and patients with ocular toxoplasmosis (Table 4). The same is true for the population of this study, which includes, for the first time in Brazil, individuals with beta hemoglobinopathies.

Most sickle cell anemia patients and those with severe forms of beta-thalassemia depend on transfusions of blood products to improve the clinical condition resulting from these hemoglobinopathies [7, 26-29]. However, there is a risk of infections by viruses, bacteria and parasites with transfusions once serological screening is not compulsory for all microorganisms [10, 17, 18, 30-32]. Despite the lack of data on blood transfusions performed in the individuals analyzed in the current study, we should consider this risk, and more detailed studies should be performed to verify the possible transmission of pathological agents in blood transfusions.

This study did not find differences between the groups considering the serology for anti-T. gondii IgG antibodies. Similar to these results, Karakaş et al. [21] found no difference between a control group and a group of patients with beta-thalassemia major in respect to serology for these antibodies. This suggests that the treatment of patients with severe hemoglobinopathies requiring frequent red blood cell transfusions does not appear to influence the rate of infections with T. gondii. However, it should be considered that the groups compared in this study do not have mean age equivalent, and the patients present in each group come from different geographical area. Despite these inequalities, this study alone is inconclusive about any relation between patients with beta hemoglobinopathies and infection with T. gondii.

Table 3 Frequency of samples reactive for anti-T. gondii IgG antibodies stratified according to age of individuals

\begin{tabular}{llll}
\hline \multicolumn{3}{c}{$\begin{array}{l}\text { Seropositive, } \\
\mathbf{n}(\%)\end{array}$} & $\begin{array}{l}\text { Seronegative, } \\
\mathbf{n}(\%)\end{array}$ \\
\hline$G 1$ & & \\
$\leq 17$ years & $5(25.0)$ & $15(75.0)$ & $\begin{array}{l}\mathrm{p} \text {-value }=0.072 \\
\mathrm{OR}=0.34\end{array}$ \\
$\geq 18$ years & $32(49.0)$ & $33(51.0)$ & $95 \% \mathrm{Cl}=0.11-1.06$ \\
G2 & & & \\
$\leq 17$ years & 0 & $5(100.0)$ & $\begin{array}{l}\mathrm{p} \text {-value }=0.45 \\
\mathrm{OR}=0.16\end{array}$ \\
$\geq 18$ years & $2(33.0)$ & $4(67.0)$ & $95 \% \mathrm{Cl}=0.006-$ \\
& & & 4.36 \\
\hline
\end{tabular}

G1 sickle cell disease patients, G2 homozygous beta-thalassemia patients

Table 2 Frequencies of seropositive and seronegative samples for anti-T. gondii antibodies in the analyzed groups as determined by ELISA

\begin{tabular}{|c|c|c|c|c|c|c|c|c|}
\hline & \multicolumn{4}{|c|}{$\lg M$} & \multicolumn{4}{|c|}{ IgG } \\
\hline & \multicolumn{2}{|c|}{ Seropositive } & \multicolumn{2}{|c|}{ Seronegative } & \multicolumn{2}{|c|}{ Seropositive } & \multicolumn{2}{|c|}{ Seronegative } \\
\hline & $n$ & $\%$ & $\mathrm{n}$ & $\%$ & $\mathrm{n}$ & $\%$ & $\mathrm{n}$ & $\%$ \\
\hline G1 $(n=85)$ & 0 & & 85 & 100 & 37 & 43.5 & 48 & 56.5 \\
\hline $\mathrm{G} 2(\mathrm{n}=11)$ & 0 & & 11 & 100 & 2 & 18.1 & 9 & 81.9 \\
\hline $\mathrm{G} 3(\mathrm{n}=62)$ & 2 & 3.2 & 60 & 96.8 & 31 & 50 & 31 & 50 \\
\hline
\end{tabular}

$\mathrm{G} 1$ vs. $\mathrm{G} 2 \rightarrow \mathrm{p}$-value $=0.1904 ; \mathrm{OR}=3.47 ; 95 \% \mathrm{Cl}=0.70-17.03$

$\mathrm{G} 1$ vs. $\mathrm{G} 3 \rightarrow \mathrm{p}$-value $=0.5038 ; \mathrm{OR}=0.77 ; 95 \% \mathrm{Cl}=0.40-1.49$

$\mathrm{G} 2$ vs. $\mathrm{G} 3 \rightarrow \mathrm{p}$-value $=0.0972 ; \mathrm{OR}=0.22 ; 95 \% \mathrm{Cl}=0.04-1.11$

G1 sickle cell disease patients, $G 2$ homozygous beta-thalassemia patients, $G 3$ heterozygous beta-thalassemia minor patients 
Table 4 Frequency of T. gondii infection in different populations from Rio de Janeiro and São Paulo state, Brazil

\begin{tabular}{|c|c|c|c|c|c|}
\hline City & $\%$ & $\mathrm{~N}$ & Population & Age range (years) & Reference \\
\hline \multicolumn{6}{|l|}{ São Paulo State } \\
\hline Botucatu & 60.0 & 913 & Pregnant women & No information & {$[36]$} \\
\hline Presidente Prudente & 33.8 & 80 & Students & $18-35$ & {$[37]$} \\
\hline São José do Rio Preto & 64.1 & 1006 & Pregnant women & $12-44$ & {$[38]$} \\
\hline São José do Rio Preto & 74.5 & 349 & Ophthalmology & $18-88$ & {$[39]$} \\
\hline São José do Rio Preto & 54 & 312 & Blood donors & $27.5 \pm 6.9$ & {$[40]$} \\
\hline São Paulo & 22 & 262 & Ophthalmology & $4-88$ & {$[41]$} \\
\hline Araraquara & 58 & 233 & Pregnant women & $18-20$ & {$[42]$} \\
\hline São Carlos & 50 & 62 & Beta-thalassemia heterozygous & $24-92$ & This study \\
\hline \multicolumn{6}{|l|}{ Rio de Janeiro State } \\
\hline Campos dos Goytacazes & 90.0 & 110 & Ophthalmology & $6-35$ & {$[43]$} \\
\hline Santa Rita de Cássia, Barra Mansa & 65.9 & 1071 & Ophthalmology & 6 months -88 & {$[44]$} \\
\hline Rio de Janeiro & 21.8 & 839 & Students & $20-30$ & {$[45]$} \\
\hline Miracema & 75.1 & 832 & Pregnant women & No information & {$[46]$} \\
\hline Rio de Janeiro & 18.1 & 11 & Beta-thalassemia homozygous & $7-59$ & This study \\
\hline Rio de Janeiro & 43.5 & 85 & Sickle cell anemia & $6-63$ & This study \\
\hline
\end{tabular}

As no statistically significant difference in the frequencies of $T$. gondii infection was observed between groups, it is possible that all patients were infected mainly by natural means (water and food containing oocysts), and that the transfusion of red blood cells does not constitute a risk factor for infection.

In this study, the differences in mean ages between groups may be explained by the fact that the carriers of these two serious diseases (sickle cell anemia and homozygous beta-thalassemia) are referred to treatment centers very early in their lives [11, 12, 27, 29, 33-35]. Thus, the samples are from young patients who are under treatment and consequently these two groups had lower mean ages compared to the group of patients with heterozygous beta-thalassemia.

When comparing the sickle cell anemia patients by age group (pediatric vs. adult patients), there is a tendency of lower risk of infection among young people. Older people have a higher cumulative exposure to the risks of becoming infected with $T$. gondii, since they have had more contact with the forms of transmission of the parasite $[11,39$, 47-49]. This was not observed in individuals with heterozygous beta-thalassemia because there were no under 18-year-old individuals in the group or, for patients with homozygous beta-thalassemia, because the number of patients was too small.

Carriers of these hemoglobinopathies that are treated with transfusions should receive filtered packed red blood cells, that is, the leucocytes should be removed from whole blood during the fractionation process [27, $30,50-52]$. One should remember that, as a rule, T. gondii is an intracellular parasite that is found in peripheral leukocytes. Thus, the use of leukocyte filters may be an important factor contributing to a reduction in the transfusion-related transmission of toxoplasmosis [30, 32, 51].

However, this study did not evaluate the transfused blood components nor the filters discarded after transfusions, which may be an excellent way to evaluate $T$. gondii infection particularly as the method is non-invasive and the filters are thrown away.

\section{Conclusions}

A comparison by age of patients with sickle cell anemia showed a trend of lower risk of infection among younger individuals. Patients with beta-thalassemia and sickle cell anemia in Brazil are infected by T. gondii as seen by the presence of anti-T. gondii IgM and IgG antibodies.

\footnotetext{
Abbreviations

T. gondii: Toxoplasma gondii; IgG: immunoglobulin G; IgM: immunoglobulin M; PCR: polymerase chain reaction; ELISA: enzyme-linked immunosorbent assay; EDTA: ethylenediaminetetraacetic acid.

Authors' contributions

CCBM corresponding author, head of the FAMERP Toxoplasma Research Group, was responsible to concept and design of the study; IFE, CLCL, ORJr performed the inclusion of patients, sample collection, and develop the clinical evaluation and clinical analyses. MNF, GCSC, APFS develop the laboratorial diagnosis. MNF, GCSC, CCBM, CRBD and LCM were responsible for the analysis and manuscript writing. All authors read and approved the final manuscript.

\section{Author details}

${ }^{1}$ Department of Biology, Universidade Estadual Paulista "Júlio de Mesquita Filho", Instituto de Biociências, Letras e Ciências Exatas-IBILCE-UNESP, São José do Rio Preto, SP, Brazil. ${ }^{2}$ Immunogenetics Laboratory, Department of Molecular Biology, Faculdade de Medicina de São José do Rio Preto-FAMERP, Avenida Brigadeiro Faria Lima, 5416, São José do Rio Preto, SP 15090-000, Brazil.

${ }^{3}$ FAMERP Toxoplasma Research Group, Faculdade de Medicina de São José do Rio Preto, São José do Rio Preto, SP, Brazil. ${ }^{4}$ Clinical Hematology Division,
} 
Instituto de Hematologia Arthur de Siqueira Cavalcanti-HEMORIO, Rio de Janeiro, RJ, Brazil. ${ }^{5}$ Department of Medicine, Faculdade de Medicina de São José do Rio Preto-FAMERP, São José do Rio Preto, SP, Brazil. ${ }^{6}$ Regional Blood Center-Hemocentro de São José do Rio Preto-Fundação Faculdade Regional de Medicina-FUNFARME, São José do Rio Preto, SP, Brazil. ${ }^{7}$ Present Address: Faculdade de Medicina Veterinária e Zootecnia, Universidade de São Paulo, São Paulo, Brazil.

\section{Acknowledgements}

We offer our deepest thanks to the Biotechnology Research Institute of Auckland University of Technology, New Zealand, particularly to Professor Stephen Henry to provide library access. Thanks to David Hewitt for help with the English version.

\section{Competing interests}

The authors declare that they have no competing interests.

\section{Availability of data and materials}

The datasets generated and analysed during the current study are available from the corresponding author on reasonable request.

\section{Ethics approval and consent to participate}

This study was approved by the Ethics Committees of the Universidade Estadual Paulista "Uúlio de Mesquita Filho", Instituto de Biociências, Letras e Ciências Exatas (UNESP/IBILCE), and the Faculdade de Medicina in São José do Rio Preto (FAMERP) and the Instituto de Hematologia Arthur de Siqueira Cavalcanti, Rio de Janeiro (HEMORIO). Individuals who agreed to participate were informed about the nature of the study and all subjects and the parents or legal guardians of under 18-years-old signed informed consent forms.

\section{Funding}

This study was supported by grants from the FAPERP (Fundação de Apoio à Pesquisa e Extensão de São José do Rio Preto) to CCBM and to MNF and by FAPESP (Fundação de Amparo à Pesquisa do Estado de São Paulo, Brazil) 2011/15570-1 to GCSC; 2012/07716-9 to LCM; 2014/01706-7 to MNF; 2015/04677-0 to (CBM). The opinions, assumptions, and conclusions or recommendations expressed in this material are responsibility of the authors and do not necessarily reflect the views of FAPESP. The funders had no role in study design, data collection and analysis, decision to publish, or preparation of the manuscript.

\section{Publisher's Note}

Springer Nature remains neutral with regard to jurisdictional claims in published maps and institutional affiliations.

Received: 4 February 2016 Accepted: 5 June 2017 Published online: 14 June 2017

\section{References}

1. Serjeant GR. The natural history of sickle cell disease. Cold Spring Harb Perspect Med. 2013;3:a011783.

2. Steinberg MMH. Nitric oxide-based treatment for sickle cell leg ulcers? Lancet Haematol. 2014;1:e86-7.

3. Cançado RD, Jesus JA. A doença falciforme no Brasil. Rev Bras Hematol Hemoter. 2007;29:204-6.

4. Silva RB, Ramalho AS, Cassorla RMS. A anemia falciforme como problema de Saúde Pública no Brasil. Rev Saúde Públ. 1993;27:54-8.

5. Higgs DR, Engel JD, Stamatoyannopoulos G. Thalassaemia. Lancet. 2012;379:373-83.

6. Greene DN, Vaughn CP, Crews BO, Agarwal AM. Advances in detection of hemoglobinopathies. Clin Chim Acta. 2015;439:50-7.

7. Aydinok Y. Thalassemia. Hematology. 2012;17(Suppl 1):S28-31.

8. Galanello R, Origa R. Beta-thalassemia. Orphanet J Rare Dis. 2010;5:11.

9. Chintakuntlawar A, Kidd M, Al-Kali A, Wilson W, Thompson CA. Toxoplasmosis in patients with hematologic malignancies. Leuk Lymphoma. 2014;56:1-3.
10. McGann PT. Sickle cell anemia: an underappreciated and unaddressed contributor to global childhood mortality. J Pediatr. 2014;165:18-22.

11. Sabarense AP, Lima GO, Silva LML, Viana MB. Characterization of mortality in children with sickle cell disease diagnosed through the Newborn Screening Program. J Pediatr. 2014;91:242-7.

12. Wang WC. Newborn screening for sickle cell disease: necessary but not sufficient. J Pediatr. 2015;91:210-2.

13. Robert-Gangneux F, Dardé MML. Epidemiology of and diagnostic strategies for toxoplasmosis. Clin Microbiol Rev. 2012;25:264-96.

14. Harker KKS, Ueno N, Lodoen MMB. Toxoplasma gondii dissemination: a parasite's journey through the infected host. Parasite Immunol. 2015;37:141-9.

15. Esch KJ, Petersen CA. Transmission and epidemiology of zoonotic protozoal diseases of companion animals. Clin Microbiol Rev. 2013;26:58-85.

16. Dubey JP, Lago EG, Gennari SM, Su C, Jones JL. Toxoplasmosis in humans and animals in Brazil: high prevalence, high burden of disease, and epidemiology. Parasitology. 2012;139:1375-424.

17. Siegel SE, Lunde MN, Gelderman AH, Halterman RH, Brown JA, Levine AS, Graw RG. Transmission of toxoplasmosis by leukocyte transfusion. Blood. 1971;37:388-94.

18. Pereira BI, Nazareth C, Malcata L, Alves H, Fernández JR, Sargento C, da Cunha S. Transfusion-transmitted protozoal infections: what is the risk in non-endemic countries? Acta Méd Port. 2011;24(Suppl 4):897-906.

19. Vaz RSRRS, Guimarães ATBA, Bonanato LD, Thomaz-Soccol V. Technical evaluation of serological screening tests for anti-Toxoplasma gondii antibodies to prevent unnecessary transfusion risks. Rev Bras Hematol Hemoter. 2008;30:277-80.

20. Amorim L. Toxoplasmosis and blood transfusion. Rev Bras Hematol Hemoter. 2008;30:259-65.

21. Karakaş S, Ozlem S, Karakas S, Ozlem S, Metin Tellioglu A, Ertabaklar H, Ertug S. Investigation of anti-Toxoplasma gondii lgG and IgM antibodies in beta-thalassemia major patients in Aydın province. Turk J Parasitol. 2012;36:133-6.

22. Saiki RK, Scharf S, Faloona F, Mullis KB, Horn GT, Erlich HA, Arnheim $\mathrm{N}$. Enzymatic amplification of beta-globin genomic sequences and restriction site analysis for diagnosis of sickle cell anemia. Science. 1985;230:1350-4.

23. Araújo AS, Silva WAJ, Leão SAC, Bandeira FCGM, Petrou M, Modell B, Zago MA. A different molecular pattern of beta-thalassemia mutations in northeast Brazil. Hemoglobin. 2003;27:211-7.

24. Reichert VCD, de Castro SM, Wagner SC, de Albuquerque DM, Hutz MH, Leistner-Segal S. Identification of beta thalassemia mutations in South Brazilians. Ann Hematol. 2008;87:381-4.

25. Bertholo LC, Moreira HW. Amplificação gênica alelo-específica na caracterização das hemoglobinas S, C e D e as interações entre elas e talassemias beta. J Bras Patol Med Lab. 2006;42:245-51.

26. Chou ST. Transfusion therapy for sickle cell disease: a balancing act. Hematol/Educ Progr Am Soc Hematol Am Soc Hematol Educ Progr. 2013;2013:439-46.

27. Yawn BP, Buchanan GR, Afenyi-Annan AN, Ballas SK, Hassell KL, James AH, Jordan L, Lanzkron SM, Lottenberg R, Savage WJ, Tanabe PJ, Ware RE, Murad MH, Goldsmith JC, Ortiz E, Fulwood R, Horton A, John-Sowah J. Management of sickle cell disease: summary of the 2014 evidence-based report by expert panel members. JAMA. 2014;312:1033-48.

28. Hankins JSJJS, Aygun B, Nottage K, Thornburg C, Smeltzer MP, Ware RE, Wang WC. From infancy to adolescence: fifteen years of continuous treatment with hydroxyurea in sickle cell anemia. Medicine. 2014;93:215.

29. de Castro Lobo CL, Ballas SK, Domingos ACB, Moura PG, do Nascimento EM, Cardoso GP, de Carvalho SM. Newborn screening program for hemoglobinopathies in Rio de Janeiro, Brazil. Pediatr Blood Cancer. 2014;61:34-9.

30. Martins PRJ, Martins RA. The importance of hemovigilance in the transmission of infectious diseases. Rev Bras Hematol Hemoter. 2013;35:180-4.

31. Garcia MN, Woc-Colburn L, Rossmann SN, Townsend RL, Stramer SL, Bravo M, Kamel H, Beddard R, Townsend M, Oldham R, Bottazzi ME, Hotez PJ, Murray KO. Trypanosoma cruzi screening in Texas blood donors, 2008-2012. Epidemiol Infect. 2014:1-4.

32. Martins PRJ, Moraes-Souza H, Silveira TB. Morbimortalidade em doença falciforme. Rev Bras Hematol Hemoter. 2010;32:378-83. 
33. Ramalho A, Magna L. Government Directive MS\# 822/01: unique aspects of hemoglobinopathies for public health in Brazil. Cad Saúde Públ. 2003:19:1195-9.

34. Hsien HCH, Carvalhaes JTAJJTAJ, Braga JJAP. Pressão arterial em crianças portadoras de doença falciforme. Rev Paul Pediatr. 2012;30:87-92.

35. Sonati MD, Costa FF. The genetics of blood disorders: the hereditary hemoglobinopathies. J Pediatr. 2008;84(4 Suppl):S40-51.

36. Olbrich Neto J, Meira DA. Soroprevalência de vírus linfotrópico de células Thumanas, vírus da imunodeficiência humana, sífilis e toxoplasmose em gestantes de Botucatu-São Paulo-Brasil: fatores de risco para vírus linfotrópico de células T humanas. Rev Soc Bras Med Trop. 2004;37:28-32.

37. de Oliveira Souza C, Tashima NT, Rita MA, Tumitan P. Estudo transversal de toxoplasmose em alunas de um curso superior da região de Presidente Prudente, Estado de São Paulo. Rev Soc Bras Med Trop. 2010;43:59-61.

38. Rodrigues ACF, Uezato S, Vono MB, Pandossio T, Spegiorin LCJF, Oliani AH, Vaz Oliani DCM, Brandão de Mattos C, de Mattos LC. Non-association between anti-Toxoplasma gondii antibodies and $\mathrm{ABO}$ blood group system. JVenom Anim Toxins Trop Dis. 2011;17:184-9.

39. Ferreira A, De Mattos CCB, Frederico FB, Meira CS, Almeida GC, Nakashima F, Bernardo CR, Pereira-Chioccola VL, De Mattos LC. Risk factors for ocular toxoplasmosis in Brazil. Epidemiol Infect. 2014;142:142-8.

40. Nakashima F et al. Prevalence of antibody class lgG anti-Toxoplasma gondii in blood donos in São José do Rio Preto and region. 2013 (FAMERPUTMB: emerging infections in the Americas-common interests and collaboration between Brazil and USA) :CD

41. Gouveia EB, Yamamoto JH, Abdalla M, Hirata CE, Kubo P, Olivalves E. Causas das uveítes em serviço terciário em São Paulo, Brasil. Arq Bras Oftalmol. 2004;67:139-45

42. Isabel TF, da Costa P, Simões MJS. Toxoplasmosis in pregnant women from Araraquara/SP: analysis of Toxoplasma-specific IgG avidity test utilization in the prenatal care routine [Abstract in English]. Sci Med. 2007;17:57-62.

43. Petersen E, Pollak A, Reiter-Owona I. Recent trends in research on congenital toxoplasmosis. Int J Parasitol. 2001;31:115-44.
44. Aleixo AL, Benchimol El, Neves ED, Silva CS, Coura LC, Amendoeira MR. Frequência de lesões sugestivas de toxoplasmose ocular em uma população rural do Estado do Rio de Janeiro. Rev Soc Bras Med Trop. 2009:42:165-9.

45. Vicente RT, Millar PR, Nicolau JL, Soares De Souza MM, Klein CH, Sudré AP, Reis Amendoeira MR. Seroepidemiology of Toxoplasma gondii infection in studentes of veterinary medicine and other courses of public universities in Rio de Janeiro state, Brazil. Rev Patol Trop. 2014;43:313-22.

46. Ribeiro AC, Mutis MS, Fernandes O. Association of the presence of residual anti-Toxoplasma gondii lgM in pregnant women and their respective family groups in Miracema, Northwest Rio de Janeiro, Brazil. Mem Inst Oswaldo Cruz. 2008;103:591-4.

47. Soares ACN, Samico IC, Araújo AS, Bezerra MAC, Hatzlhofer BLD. Followup of children with hemoglobinopathies diagnosed by the Brazilian Neonatal Screening Program in the State of Pernambuco. Rev Bras Hematol Hemoter. 2014:36:250-5.

48. Lima ARG, Ribeiro VS, Nicolau DI. Trends in mortality and hospital admissions of sickle cell disease patients before and after the newborn screening program in Maranhão, Brazil. Rev Bras Hematol Hemoter. 2014;37:12-6.

49. Viana MB. The invisibility of sickle cell disease in Brazil: lessons from a study in Maranhão. Rev Bras Hematol Hemoter. 2014;37:5-6.

50. Wanko SO, Telen MJ. Transfusion management in sickle cell disease. Hematol/oncol Clin N Am. 2005;19:803-26.

51. Carneiro-Proietti AB. Hemovigilance: a system to improve the whole transfusion chain. Rev Bras Hematol Hemoter. 2013;35:158-9.

52. Cappellini M, Cohen A, Eleftheriou A, Piga A, Porter J, Taher A. Guidelines for the clinical management of Thalassaemia. 2nd ed. Nicosia: Thalassaemia International Federation; 2008.

\section{Submit your next manuscript to BioMed Central and we will help you at every step:}

- We accept pre-submission inquiries

- Our selector tool helps you to find the most relevant journal

- We provide round the clock customer support

- Convenient online submission

- Thorough peer review

- Inclusion in PubMed and all major indexing services

- Maximum visibility for your research

Submit your manuscript at www.biomedcentral.com/submit
O Biomed Central 